\title{
PENGARUH GAYA HIDUP, LABEL HALAL DAN HARGA TERHADAP KEPUTUSAN PEMBELIAN KOSMETIK (Studi Kasus Pada Produk Safi)
}

\author{
Ayif Fathurrahman; Martyas Anggesti \\ Universitas Muhammadiyah Yogyakarta \\ e-mail: ayief_ospp@yahoo.com; martyasanggesti15@gmail.com
}

\begin{abstract}
Style development changes every year. Indonesia, where the population majority is Muslim, is now developing an Islamic lifestyle. This style development can be supported by the inclusion of halal labeling on product packaging. The halal label on the product guarantees that the product is safe for consumption or use. Muslim consumers will consider this before making a purchase indeed. Safi product is a cosmetic product that is halal and safe because they do not contain harmful ingredients. This study aims to analyze the purchasing decision of students for Safi Cosmetics at Universitas Muhammadiyah Yogyakarta and what factors influence the purchasing decision for Safi Cosmetics. This study used data from 120 people. The sample collection used the purposive sampling technique and multiple regression analysis in analyzing primary data. The analytical tool used in this study is the SPSS version 21.0 for windows software. The results obtained in this study are lifestyle variables, halal labels, and prices have a positive and significant effect on students' purchasing decisions for Safi Cosmetic at Universitas Muhammadiyah Yogyakarta. This study shows that the coefficient of determination is 0.484 or 48.4\%. The decision of students at the Universitas Muhammadiyah Yogyakarta to purchase Safi Cosmetics can be shown that $48.4 \%$ is influenced by lifestyle, halal labels, and prices. Meanwhile, $51.6 \%$ is explained by other variables outside the model.
\end{abstract}

Keywords: lifestyle; halal label; price; purchase decision

\section{Pendahuluan}

Indonesia adalah negara dengan penduduk muslim terbanyak di dunia. Hal ini menunjukan tren positif secara tidak langsung membawa peningkatan terhadap adanya permintaan produk halal secara global. Bagi masyarakat muslim, produk halal adalah sebuah keharusan. Ketika berbicara tentang kehalalan suatu produk tidak bisa terlepas dari konsep tayyib. Jika halal mengacu pada hukum boleh atau tidaknya suatu produk dikonsumsi, tayyib lebih menekankan pada aspek kualitas produk seperti kandungan gizi, kebersihan dan keamanan produk, kesehatan, keterjangkauan harga, serta manfaat lainnya. Konsep tayyib pada produk halal mensyaratkan produsen memproduksi produk yang benar-benar berkualitas dan bermanfaat.

Selain itu, permintaan halal saat ini tidak hanya berfokus pada makanan tetapi juga menangkap kategori produk non makanan lainnya, seperti kosmetik. Kosmetik halal sendiri dari tahun ke tahun mengalami peningkatan yang cukup pesat, hal ini terlihat dari banyaknya produk baru atau produk yang awal mulanya tidak berlabel halal, saat ini mulai memberikan label halal pada produknya. Salah satu kosmetik berlabel halal yang sedang digemari oleh kaum wanita khususnya mahasiswi adalah produk kosmetik bermerek Safi. 
Di dunia persaingan antara pasar industri kosmetik dan perawatan pribadi sudah sangat kompetitif. Hal ini sudah terbukti karena sudah banyaknya jenis kosmetik produksi luar negeri maupun dalam negeri yang sudah banyak beredar di Indonesia. Dengan banyaknya macam merek produk kosmetik di pasar bisa mempengaruhi minat seseorang untuk melakukan pembelian sehingga berdampak pada keputusan pembelian. Pembelian suatu produk kosmetik saat ini bukan lagi semata untuk memenuhi kecantikan seseorang tetapi sudah menjadi kebutuhan seseorang.

Gambar 1.1. Faktor Pertimbangan Pembelian Kosmetik

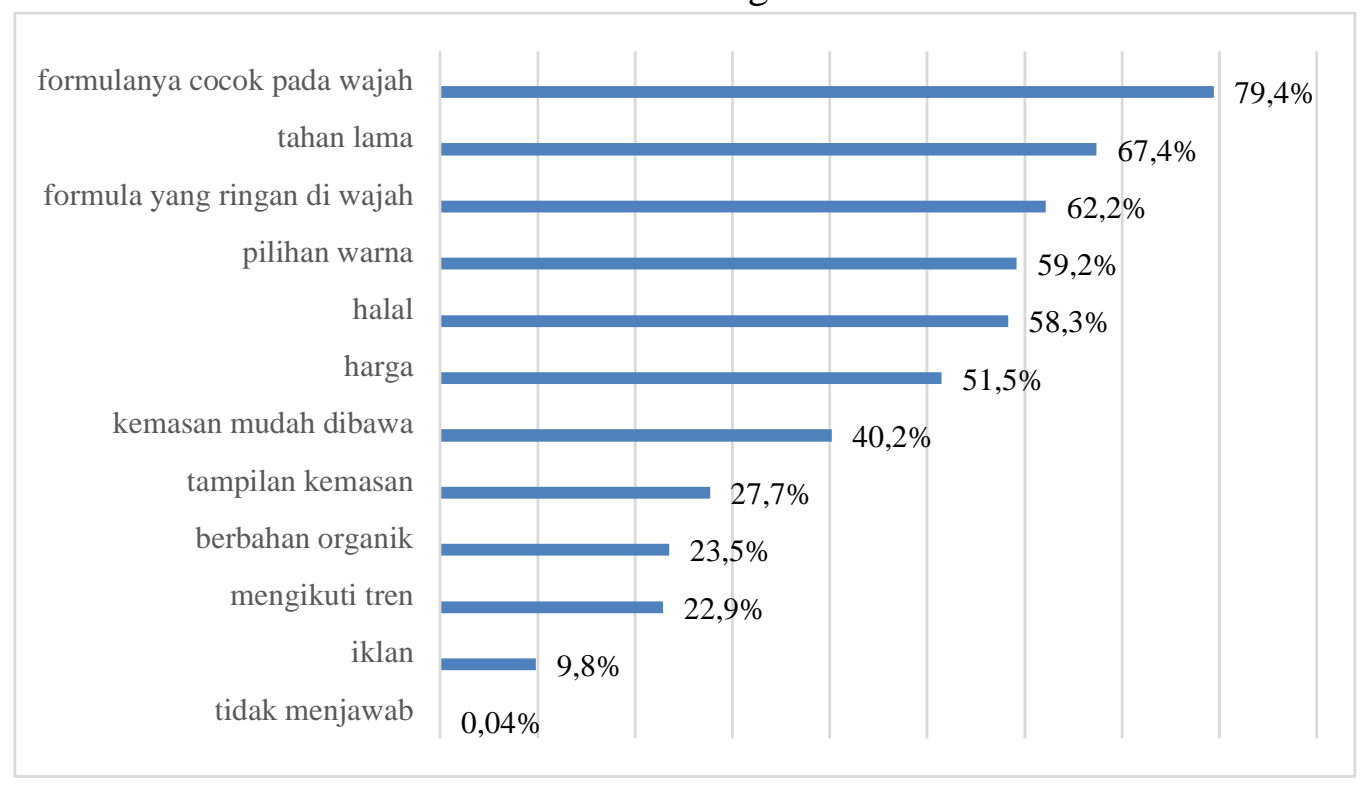

Sumber : sigma Research Indonesia

Produk kosmetik halal semakin popular seiring dengan banyaknya konsumen yang sudah mulai memperhatikan kehalalan sebuah produk. Sigma Research Indonesia melakukan survei kepada 1200 perempuan Indonesia dengan rentan usia 15-55 tahun. Dari survei tersebut menunjukan bahwa terdapat beberapa faktor yang menjadi pertimbangan wanita dalam membeli kosmetik. Hasil survei dapat digambarkan seperti pada gambar di atas yang menunjukan sebesar $58.3 \%$ aspek kehalalan produk menjadi pertimbangan pada saat membeli kosmetik. Namun formula yang cocok pada kulit menjadi pertimbangan tertinggi yakni sebesar $79.4 \%$, artinya konsumen masih belum terlalu memperhatikan label halal khususnya pada produk kosmetik.

Salah satu kosmetik halal yang sedang banyak digunakan oleh kaum hawa adalah merek Safi yang merupakan produk skincare halal asal Malaysia. Safi sudah memiliki sertifikat halal dari Jabatan Kemajuan Islam Malaysia (JAKIM) dan Majelis Ulama Indonesia (MUI). ${ }^{1}$ Target pasar Safi di Indonesia adalah wanita muslim yang mengikuti syariat hukum Islam. Produk Safi dibuat dengan syariat Islam, setidaknya dalam perdagangan Islam sah sesuai dengan syarat dan rukunnya. Untuk mendapatkan sertifikat halal berarti suatu produk sudah melewati banyak tes

\footnotetext{
${ }^{1}$ Produk Safi diluncurkan di Indonesia setelah proses riset mendalam berdasarkan keperluan dan keinginan wanita Indonesia terhadap perawatan kulit mereka. Peluncuran pertama kali produk Safi di Jakarta pada Kamis 29 Maret 2018. Ada tiga produk Safi yang diluncurkan pertama kali di Indoensia, yaitu Safi White Natural with Mangosten, Safi White expert dan Safi Age defy.
} 
dan uji coba mulai dari proses hingga kandungannya semua sesuai dengan syarat Islam dengan cara yang baik, tidak merusak, tidak menyakiti serta aman untuk digunakan dan yang pasti dibuat dari bahan-bahan yang alami dan halal.

Ada beberapa penelitian terdahulu yang terkait dengan gaya hidup dan label halal, semisal penelitian yang dilakukan oleh Tarigan (2016), Suryoko, (2016), Lalujan (2016), Rafit (2017), Muharrami (2017) Novia (2018). Hasil penelitian Tarigan (2016) menunjukan bahwa gaya hidup, label halal dan harga sebagai variabel independen secara parsial berpengaruh positif dan signifikan terhadap keputusan pembelian kosmetik Wardah pada mahasiswa Program Studi Manajemen Fakultas Ekonomi Universitas Medan Area Medan. ${ }^{2}$ Penelitian ini diperkuat dengan hasil penelitian Lalujan $(2016)^{3}$, Puspita dan Suryoko $(2016)^{4}$ dan Faadhilah $(2018)^{5}$ yang memiliki kesimpulan serupa. Penelitian yang berfokus pada pengaruh label halal juga telah dilakukan oleh Aspan (2017) yang menyimpulkan bahwa label halal berpengaruh signiikan terhadap keputusan pembelian produk kosmetik. ${ }^{6}$

\section{Metode Penelitian}

Penelitian ini merupakan penelitian kuantitatif dengan objek penelitiannya adalah kosmetik Safi. Subjek dari penelitian ini adalah para mahasiswi Universitas Muhammadiyah Yogyakarta (UMY) dari berbagai fakultas dan program studi dengan ketentuan responden yaitu mahasiswi yang menggunkan kosmetik Safi, sehingg jenis data dalam penelitian ini adalah data primer.

Metode penentuan sampel yang dipakai dalam penelitian ini adalah non probability sampling dengan jenis purposive sampling. Dalam penelitian ini ketentuan yang digunakan sebagai sampel adalah:

1. Responden yaitu mahasiswi yang masih aktif di Universitas Muhammadiyah Yogyakarta.

2. Responden yaitu mahasiswi yang menggunakan kosmetik Safi.

3. Reponden pernah melakukan pembelian kosmetik Safi minimal 1 kali.

Dalam penelitian ini populasi yang ada sebanyak 29.450 yang didapat dari jumlah keseluruhan mahasiswa Universitas Muhammadiyah Yogyakarta. Sehingga sampel yang dibutuhkan dalam penelitian ini setelah menggunakan rumus Slovin adalah 99.66 dan dibulatkan menjadi 100 responden minimal.

\footnotetext{
${ }^{2}$ Dewi Eka Setia Tarigan, "Pengaruh Gaya Hidup, Label Halal dan Harga terhadap Keputusan Pembelian Kosmetik Wardah pada Mahasiswa Program Studi Manajemen Fakultas Ekonomi Universitas Medan Area Medan", Jurnal Konsep Bisnis dan Manajemen, Volume 3, Nomor 1 (2016), 92.

${ }^{3}$ David I. O. Lalujan, dkk, "Analyzing the Influence of Brand Image, Perceived Price and Perceived Quality on Consumer Buying Decision of Low Cost Green Car (Case Study of Astra Toyota Agya at Manado)", Efisiensi, Volume 16, Nomor 4 (2016), 145-155.

${ }^{4}$ R. Puspita dan S. Suryoko, "Pengaruh Iklan, Harga dan Kepercayaan Merek Terhadap Keputusan Pembelian Kosmetik Revlon (Studi Pada Mahasiswa S1 Universitas Diponegoro)", Jurnal Ilmu Administrasi Bisnis, Volume 6, Nomor 3 (2017), 418-425.

${ }^{5}$ Fauz Novia Faadhilah, "Pengaruh Gaya Hidup Konsumtif dan Beauty Vlogger Sebagai Kelompok Referensi Terhadap Keputusan Pembelian Kosmetik Studi Kasus Pada Remaja Perempuan Pengguna Kosmetik Korea di Surabaya”, Jurnal Ilmu Manajemen, Volume 7, Nomor 1 (2018), 133-142.

${ }^{6}$ Iskandar Aspan, dkk, "The Effect of Halal Label, Halal Awarness, Product Price and Brand Image to the Purchasing Decision on Cosmetic Products (Case Study on Consumers of Sari Ayu Marta Tilaar in Binjai City), International Journal of Global Sustainability, Volume 1, Nomor 1 (2017), 72.
} 
Untuk uji instrumen data, penelitian ini menggunakan uji validitas, yaitu suatu skala pengukuran dinyatakan valid jika melakuan apa yang seharusnya diukur, jika skala pengukuran tidak dinyatakan valid maka tidak memiliki manfaat bagi peneliti. ${ }^{7}$ Penelitian ini juga menggunakan uji reliabilitas yang digunakan untuk mengukur berulang-ulang dan menghasilkan data yang sama. ${ }^{8}$ Uji asumsi klasik dilakukan agar diperoleh model analisis yang tepat untuk digunakan dalam penelitian ini. Adapun uji asumsi klasik yang dilakukan meliputi uji normalitas data secara statistik, uji multikoliniearitas dan uji heteroskedastisitas.

Sedangkan uji hipotesis dan analisis data menggunakan analisis regresi linear berganda. Metode regresi linier berganda ini digunakan untuk melihat hubungan antara variabel-variabel independen, yaitu gaya hidup (X1), label halal (X2), dan harga (X3) dengan variabel dependen, yaitu keputusan pembelian kosmetik Safi (Y). Model persamaan yang digunakan yaitu:

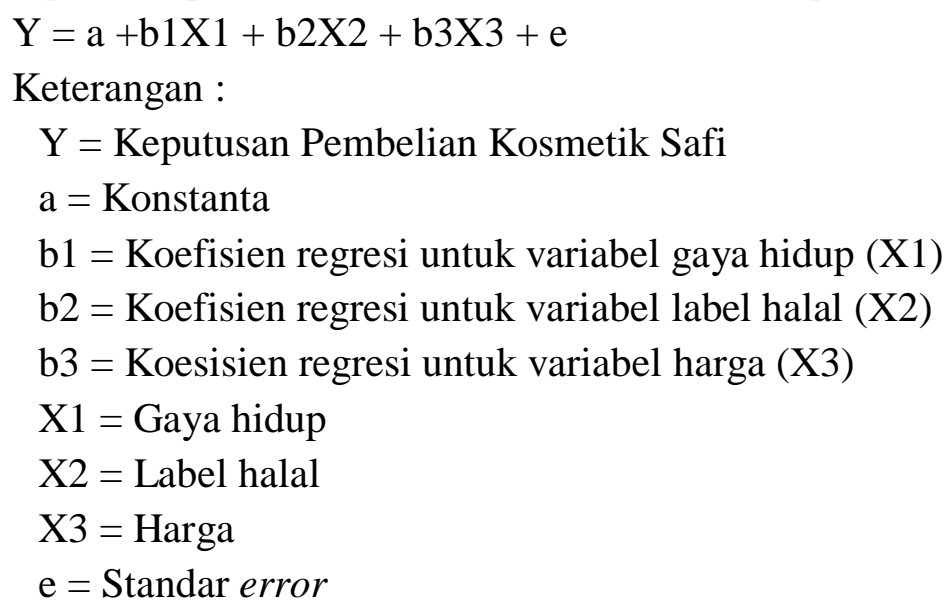

\section{Gaya Hidup}

Gaya hidup merupakan pola hidup seseorang yang dinyatakan dalam kegiatan, minat dan pendapatnya dalam membelanjakan uangnya dan mengalokasikan waktu yang dimilikinya. ${ }^{9}$ Gaya hidup dapat dijadikan jendela dari kepribadian masing-masing individu. Gaya hidup merupakan pola hidup seseorang di dunia yang dieksprsikan dalam aktivitas, minat dan opininya. Gaya hidup menggambarkan "keseluruhan diri seseorang" dalam berinteraksi dengan lingkungannya. Gaya hidup menggambarkan seluruh pola seseorang dalam beraksi dan berinteraksi di dunia. Secara umum dapat diartikan sebagai suatu gaya hidup yang dikenali dengan bagaimana orang menghabiskan waktunya (aktivitas), apa yang penting orang pertimbangkan dalam lingkungan (minat) dan apa yang orang pikirkan tentang diri sendiri dan dunia sekitar (opini). Gaya hidup adalah perilaku seseorang yang ditunjukan dalam aktivitas, minat dan opini khususnya yang berkaitan dengan citra diri untuk merefleksikan status sosialnya. ${ }^{10}$

Menurut Hawkins, seperti yang dikutip oleh Yuniarti, gaya hidup seseorang mempengaruhi kebutuhan, keinginan serta perilaku termasuk perilaku membeli. Gaya hidup juga sering dijadikan sebagai motivasi dasar dan pedoman dalam membeli sesuatu. Hal ini

\footnotetext{
${ }^{7}$ A. T. Basuki, Ekonometrika dan Aplikasi dalam Ekonomi (Yogyakarta: Danisa Media, 2017), 86.

${ }^{8}$ Sugiono, Metode Penelitian Bisnis (Bandung: Alfabeta, 2018), 58.

${ }^{9}$ Ujang Sumarwan, Perilaku Konsumen (Teori dan Penerapannya dalam Pemasaran) (Bogor: Penerbit Ghalia Indonesia, 2004), 257.

${ }^{10}$ Philip Kotler dan Lane Keller, Manajemen Pemasaran (Jakarta: Erlangga Pearson Education, 2009$), 152$.
} 
berarti, seseorang dalam melakukan pembelian suatu produk mengacu pada gaya hidup yang dianutnya. Pada saat ini gaya hidup sangat dipengaruhi oleh perkembangan zaman dengan memperhatikan mode atau tren yang sedang berlangsung. ${ }^{11}$ Brandon dan Fomey menyatakan bahwa gaya hidup berasal dari nilai-nilai dasar individu yang mendasari perilaku konsumen seseorang yang dapat mencontohkan suatu tren dan gaya hidup berpenampilan orang tersebut. Salah satunya dengan menggunakan produk-produk yang memiliki merek eksklusif dan mahal. $^{12}$

\section{Label Halal}

Masyarakat banyak memainkan peran efektif dalam membentuk kebiasaan dan komitmen agama memainkan peran penting dalam kehidupan orang-orang melalui pembentukan keyakinan, pengetahuan dan sikap. Berdasarkan aturan Islam, telah jelas menganggap produk haram, yaitu konsumsi minuman alkohol, daging babi, darah, mayat dan daging yang tidak disembelih. Makanan halal dianggap sebagai makanan khusus yang ditentukan oleh gizi Islam. Mengkonsumsi makanan halal adalah untuk menghormati ajaran agama mereka.

Makna kata halal berasal dari bahasa Arab yang berarti "melepaskan" dan "tidak terikat". Secara etimologi, halal berarti hal-hal yang boleh dan dapat dilakukan karena bebas atau tidak terikat dengan ketentuan-ketentuan yang boleh dan dapat dilakukan karena bebas atau tidak terikat dengan ketentuan-ketentuan yang melarangnya. ${ }^{13}$

\section{Harga}

Harga adalah sejumlah uang yang ditagihkan atas suatu produk atau jasa dari nilai yang ditukarkan para pelanggan untuk memperoleh manfaat dari memiliki atau menggunakan suatu produk atau jasa. Harga juga merupakan elemen bauran pemasaran yang paling fleksibel. Tidak seperti fitur produk atau komitmen penyalur, harga dapat berubah dengan cepat. ${ }^{14}$ Dalam menetapkan harga perusahaan harus mempertimbangkan faktor dalam menentukan kebijakan penetapan harganya, sehingga harga yang nantinya ditetapkan dapat diterima oleh konsumen. Faktor-faktor yang berpengaruh dalam penetapan harga tersebut adalah: ${ }^{15}$

1. Biaya menjadi batas bawah.

2. Harga pesaing dan harga barang pengganti menjadi titik orientasi yang perlu dipertimbangkan perusahaan.

3. Penilaian pelanggan terhadap fitur-fitur produk yang unik dari penawaran perusahaan menjadi batas atas harga. Setelah mempertimbangkan faktor-faktor yang menentukan penetapan harga, perusahaan kini siap untuk memilih suatu harga. Perusahaan memecahkan permasalahan harga dengan menggunakan metode penetapan harga.

\section{Gambaran Umum Subjek Penelitian}

Terdapat lima pernyataan demografi yang diajukan sebelum calon responden menjawab pertanyaan atau pernyataan yang terdapat pada kuesioner. Adapun data demografi yang

\footnotetext{
${ }^{11}$ Vinna Sri Yuniarti, Perilaku Kosumen Teori dan Praktik (Bandung: Pustaka Setia, 2015), 133.

${ }^{12}$ Ibid., 135.

${ }^{13}$ A. Girinda, Dari Sertifikat Menuju Labelisasi Halal: LPPOM MUI (Jakarta: Pustaka Jurnal Halal, 2008), 88.

${ }^{14}$ Philip Kottler dan Gary Amstrong, Manajeman Pemasaran, Jilid 1 (Jakarta: Ghalia Indonesia, 2001), 162.

${ }^{15}$ Philip Kotler dan Lane Keller, Manajemen Pemasaran, 154.
} 
diajukan di antaranya usia, status, jurusan, fakultas dan jumlah pembelian. Data demografi yang diolah disajikan dalam bentuk tabel dan data sebagai berikut.

\section{Usia Responden}

Data rentan usia mahasiswi Universitas Muhammadiyah Yogyakarta yang menjadi responden dalam penelitian ini yang berusia 18 tahun berjumlah 1 orang dengan presentase $0.8 \%, 19$ tahun berjumlah 9 orang dengan presentase $7.5 \%$, responden yang berusia 20 tahun berjumlah 23 orang dengan presentase $19.1 \%$ dan responden yang berusia 21 tahun berjumlah 73 orang dengan presentase $60.8 \%, 22$ tahun berjumlah 10 orang dengan presentase $8.3 \%, 23$ tahun berjumlah 3 orang dengan presentase $3.5 \%$ dan 24 tahun berjumlah 1 orang dengan presentase $0.8 \%$.

Tabel 1.1. Karakteristik Responden Berdasarkan Usia

\begin{tabular}{|c|c|c|c|}
\hline No & Usia & Jumlah & Presentase (\%) \\
\hline 1 & 18 & 1 & 0.8 \\
\hline 2 & 19 & 9 & 7.5 \\
\hline 3 & 20 & 23 & 19.1 \\
\hline 4 & 21 & 73 & 60.8 \\
\hline 5 & 22 & 10 & 8.3 \\
\hline 6 & 23 & 3 & 3.6 \\
\hline 7 & 24 & 1 & 0.8 \\
\hline & Total & 120 & 100 \\
\hline
\end{tabular}

Status Responden

Tabel 1.2. Karakteristik Responden Berdasarkan Status

\begin{tabular}{|c|c|c|c|}
\hline No & Status & Jumlah & Presentase (\%) \\
\hline 1 & Belum menikah & 120 & 100 \\
\hline 2 & Menikah & 0 & 0 \\
\hline & Total & 120 & 100 \\
\hline
\end{tabular}

Data pada tabel 1.2. di atas menunjukan bahwa dengan total 120 responden yang telah mengisi kuesioner dengan lengkap jumlah responden pada penelitian ini didominasi oleh status belum menikah yang berjumlah 120 orang dengan presentase $100 \%$.

\section{Jumlah Pembelian}

Pada tabel 1.3. di bawah ini adalah jumlah pembelian kosmetik Safi yang dilakukan mahasiswi Universitas Muhammadiyah Yogyakarta yang menjadi responden dalam penelitian ini, yaitu 1 sampai 3 kali berjumlah 93 orang dengan presentase $78 \%$ dan $>3$ kali berjumlah 27 orang dengan presentase $22 \%$. 
Tabel 1.3. Karakteristik Responden Berdasarkan Jumlah Pembelian

\begin{tabular}{|c|c|c|c|}
\hline No & Jumlah Pembelian & Jumlah & Presentase (\%) \\
\hline 1 & $1-3$ kali & 93 & 78 \\
\hline 2 & $>3$ kali & 27 & 22 \\
\hline & Total & 120 & 100 \\
\hline
\end{tabular}

\section{Uji Validitas}

Uji validitas dilakukan untuk mengetahui valid atau tidak kuesioner yang diberikan kapada responden. Dengan menggunakan SPSS versi 21.0, validnya suatu data di mana $r$ hitung $\geq \mathrm{r}$ tabel maka dapat dikatakan valid. Dapat dilihat bahwa $r$ tabel sebesar 0.1779 lebih besar dari $r$ hitung, jadi kesimpulannya semua variabel yang ada dikatakan valid.

\section{Uji Reliabilitas}

Uji reliabilitas untuk mengukur nilai yang ada pada pada variabel kuesioner sehingga dapat menghasilkan data yang konsisten dengan menggunakan alat uji statistik SPSS versi 21.0, dapat dikatakan reliable apabila cronbach's alpha lebih besar dari 0,06.

\section{Uji Normalitas}

Hasil uji Kolmogorov-Smirnov menunjukan nilai Kolmogorov-SmirnovZ sebesar 1.150 dengan nilai probabilitas signifikan Asymp. Sig (2-tailed) sebesar 0.142. karena nilai Asymp. Sig $>0.05$, maka dapat disimpulkan bahwa data residual terdistribusi secara normal. Dengan kata lain, model regresi penelitian ini terdistribusi normal. Maka dari itu, dapat dilakukan uji selanjutnya, yaitu uji multikolinearitas.

\section{Uji Multikolinearitas}

Hasil pengujian multikolinearitas di mana nilai VIF dalam penelitian ini mempunyai nilai tolerance $>0.1$, yaitu pada variabel gaya hidup sebesar 0.626, variabel label halal sebesar 0.743 dan variabel harga sebesar 0.815. Sedangkan nilai VIF yang didapat dalam pengujian ini yaitu nilai VIF < 10 di mana pada variabel gaya hidup nilai VIF nya sebesar 1.598, variabel label halal nilai VIF nya sebesar 1.346 dan variabel harga nilai VIFnya sebesar 1.227. Maka dapat dikatakan penelitian ini bebas dari multikolinearitas dan dapat dilakukan pengujian selanjutnya, yaitu uji heteroskedastisitas. Bahwa variabel independen, yaitu gaya hidup, label halal dan harga tidak adanya heteroskedastisitas.

\section{Uji Heteroskedastisitas}

Berdasarkan hasil pengujian heteroskedastisitas di atas menunjukan bahwa model penelitian tidak terdapat gelaja heteroskedastisitas di mana nilai signifikannya $>0.05$, yaitu pada variabel gaya hidup nilai signifikansinya sebesar 0.110 , variabel label halal nilai signifikamsinya sebesar 0.420 dan variabel harga nilai signifikansinya sebesar 0.266. Dapat disimpulkan penelitian ini memenuhi asumsi non heteroskedastisitas dan dapat dilakukan pengujian selanjutnya. 


\section{Hipotesis dan Analisis Data}

Analisis Deskriptif

Tabel 1.4. Descriptive Variabel Statistic

\begin{tabular}{|l|c|c|c|c|}
\hline \multicolumn{1}{|c|}{ Variabel } & Min & Max & Mean & Std. Deviation \\
\hline Gaya hidup (X1) & 13 & 24 & 18.16 & 2.401 \\
\hline Label halal (X2) & 8 & 16 & 12.34 & 1.481 \\
\hline Harga (X3) & 8 & 16 & 11.75 & 1.672 \\
\hline Keputusan pembelian (Y) & 10 & 20 & 15.18 & 2.260 \\
\hline
\end{tabular}

Jika dilihat dari tabel 1.4. nilai terendah untuk variabel label halal adalah 8 dan nilai tertinggi untuk variabel label halal adalah 16 . Nilai rata-rata untuk variabel label halal adalah 12.34. Selanjutnya strandar deviasi dari variabel label halal adalah 1.481 yang mana nilai ini lebih kecil dari besarnya rata-rata variabel label halal maka dapat terindikasi baik.

Nilai terendah untuk variabel harga adalah 8 dan nilai tertinggi untuk variabel harga adalah 16. Nilai rata-rata untuk harga adalah 11.75. Selanjutnya trandar deviasi dari variabel harga adalah 1.672 yang mana nilai ini lebih kecil dari besarnya rata-rata variabel harga maka dapat terindikasi baik. Adapun nilai terendah untuk variabel keputusan pembelian adalah 10 dan nilai tertinggi untuk variabel harga adalah 20. Nilai rata-rata untuk harga adalah 15.18. Selanjutnya trandar deviasi dari variabel harga adalah 2.260 yang mana nilai ini lebih kecil dari besarnya rata-rata variabel harga maka dapat terindikasi baik.

\section{Analisis Regresi Linear Berganda}

Hasil analisis regresi berganda pada penlitian ini dapat dilihat pada tabel berikut:

Tabel 1.5. Descriptive Variabel Statistic

\begin{tabular}{|l|c|c|c|}
\hline \multicolumn{1}{|c|}{ Model } & $\begin{array}{c}\text { Understandardized } \\
\text { Coefficients B }\end{array}$ & t hitung & Sig. \\
\hline (Constant) & 0.095 & 0.062 & 0.951 \\
\hline Gaya Hidup (X1) & 0.439 & 5.608 & 0.000 \\
\hline Label Halal (X2) & 0.275 & 2.360 & 0.020 \\
\hline Harga (X2) & 0.316 & 3.209 & 0.002 \\
\hline
\end{tabular}

Dari tabel 1.51 di atas dapat dilihat hasil persamaan regresi linear berganda sebagai berikut:

$\mathrm{Y}=0.095+0.439$ Gaya Hidup (X1) + 0.275 Label Halal (X2) + 0.316 Harga (X3)

Dari tabel di atas dapat diketahui hasil pengujian hipotesis sebagai berikut:

1. Konstanta $=0.095$

Nilai konstanta (a) sebesar 0.095 , nilai konstanta positif menunjukan pengaruh positif variabel independen (gaya hidup, label halal dan harga) naik atau berpengaruh dalam satu satuan, maka variabel keputusan pembelian kosmetik Safi akan naik atau terpenuhi.

2. Gaya Hidup $(\mathrm{X} 1)=0.439$

Apabila gaya hidup (X1) mengalami kenaikan sebesar 1 persen, sementara variabel lain seperti label halal (X2) dan harga (X3) dianggap tetap, maka keputusan pembelian kosmetik Safi akan mengalami peningkatan 0.439 persen. 
3. $\quad$ Label Halal $(\mathrm{X} 2)=0.275$

Apabila label halal (X2) mengalami kenaikan sebesar 1 persen, sementara variabel lain seperti gaya hidup (X1) dan harga (X3) dianggap tetap, maka keputusan pembelian kosmetik Safi akan mengalami peningkatan 0.275 persen.

4. Harga $(\mathrm{X} 3)=0.316$

Apabila harga (X3) mengalami kenaikan sebesar 1 persen, sementara variabel lain seperti gaya hidup (X1) dan label halal (X2) dianggap tetap, maka keputusan pembelian kosmetik safi akan mengalami peningkatan 0.316 persen.

\section{Uji Parsial (Uji T)}

Adapun hasil uji parsial dalam penelitian ini dapat dilihat pada tabel berikut:

Tabel 1.6. Hasil Uji Parsial (Uji T)

\begin{tabular}{|l|c|c|c|l|}
\hline \multicolumn{1}{|c|}{ Model } & $\begin{array}{c}\text { Understandardized } \\
\text { Coefficients B }\end{array}$ & $\begin{array}{c}\mathrm{T} \\
\text { hitung }\end{array}$ & Sig. & Keterangan \\
\hline (Constant) & 0.095 & 0.062 & 0.951 & \\
\hline $\begin{array}{l}\text { Gaya Hidup } \\
\text { (X1) }\end{array}$ & 0.439 & 5.608 & 0.000 & Signifikan \\
\hline $\begin{array}{l}\text { Label Halal } \\
\text { (X2) }\end{array}$ & 0.275 & 2.360 & 0.020 & Signifikan \\
\hline Harga (X2) & 0.316 & 3.209 & 0.002 & Signifikan \\
\hline
\end{tabular}

Berdasarkan tabel 1.6. di atas dapat dilihat hasil nilai t hitung pada variabel gaya hidup sebesar 5.608 lebih besar dari t tabel yang nilainya 1.980 dan nilai probabilitas pada variabel gaya hidup memiliki nilai signifikan sebesar 0.000 kurang dari 0.05 , jadi H0 ditolak dan Ha1 dapat diterima. Artinya, variabel gaya hidup secara signifikan berpengaruh terhadap keputusan pembelian kosmetik Safi. Untuk variabel label halal, dapat dilihat hasil nilai t hitungnya sebesar 2.360 lebih besar dari t tabel yang nilainya 1.980 dan nilai probabilitas pada variabel label halal memiliki nilai signifikan sebesar 0.020 kurang dari 0.05 , jadi, H0 ditolak dan Ha2 dapat diterima. Dengan kata lain, variabel label halal secara signifikan berpengaruh terhadap keputusan pembelian kosmetik Safi. Sedangkan untuk variabel harga, dapat dilihat hasil nilai t hitungnya sebesar 3.209 lebih besar dari t tabel yang nilainya 1.980 dan nilai probabilitas pada variabel harga memiliki nilai signifikan sebesar 0.002 kurang dari 0.05, jadi, H0 ditolak dan Ha3 dapat diterima. Artinya, variabel harga secara signifikan berpengaruh terhadap keputusan pembelian kosmetik Safi.

\section{Uji Simultan (Uji F)}

Adapun hasil uji simultan dalam penelitian ini dapat dilihat pada tabel di bawah ini:

Tabel 1.7. Uji F (Simultan)

\begin{tabular}{|c|c|c|}
\hline Model & F & Sig. \\
\hline Regression Residual Total & 38.254 & $0.000 \mathrm{~b}$ \\
\hline
\end{tabular}


Berdasarkan tabel 1.7. di atas, diperoleh nilai probabilitas sebesar $0.000<(0.05)$ yang berarti terdapat pengaruh yang signifikan variabel-variabel independen gaya hidup, label halal dan harga secara simultan mempengaruhi keputusan pembelian kosmetik Safi.

\section{Uji Koefisien Determinasi (R2)}

Adapun hasil uji koefisien determinasi (R2) dalam penelitian ini dapat dilihat pada tabel di bawah ini:

Tabel 1.8. Hasil Analisis Koefisien Determinasi (R2)

\begin{tabular}{|c|c|c|c|c|}
\hline Model & $\mathrm{R}$ & $\mathrm{R}$ Square & $\begin{array}{c}\text { Adjusted } \\
\text { R Square }\end{array}$ & $\begin{array}{c}\text { Std. Erorr of } \\
\text { the Estimate }\end{array}$ \\
\hline 1 & $0.705 \mathrm{a}$ & 0.497 & 0.484 & 1.623 \\
\hline
\end{tabular}

Koefisien determinan digunakan untuk melihat seberapa jauh model menerangkan variabel dependen. Nilai R2 yang kecil berarti kemampuan variasi variabel independen menjelaskan variabel dependen terbatas dan juga sebaliknya. Dari tabel 1.8. di atas, nilai Adjusted R Square sebesar 0.484 menunjukan variabel gaya hidup, label halal dan harga mampu menjelaskan variabel keputusan pembelian kosmetik Safi sebesar $48.4 \%$. Sedangkan sisanya sebesar $51.6 \%$ dijelaskan oleh variabel lain yang tidak dimasukkan dalam metode penelitian. Dalam analisis koefisien determinasi dapat dilihat bahwa kolerasi senilai 0.705 lebih dari 0.05 maka hubungan variabel independen dengan variabel dependen memiliki hubungan yang kuat di mana $\mathrm{R}>0.05$.

\section{Pengaruh Gaya Hidup terhadap Keputusan Pembelian Kosmetik Safi}

Berdasarkan hasil uji hipotesis yang menunjukan nilai signifikan sebesar 0.439 dengan nilai probabilitasnya 0.000 . Nilai probabilitas pada variabel gaya hidup lebih kecil dari 0.05 . Hal ini berarti gaya hidup mempunyai pengaruh positif signifikan terhadap keputusan pembelian, sehingga hipotesis yang menyatakan adanya pengaruh antara gaya hidup dan keputusan pembelian didukung.

Gaya hidup adalah pola yang menggambarkan kegiatan, ketertarikan dan opini individu yang berinteraksi dengan lingkungan sekitarnya. Aktivitas merupakan karakteristik konsumen dalam kehidupan sehari-harinya mengenai apa yang mereka lakukan, apa yang mereka beli dan bagaimana mereka menghabiskan waktu mereka. Ketertarikan memfokuskan pada preferensi dan prioritas konsumen. Ketertarikan merupakan faktor pribadi konsumen dalam mempengaruhi proses pengambilan keputusan. Opini merupakan pendapat dari setiap konsumen yang berasal dari pribadi mereka sendiri. ${ }^{16}$

Hasil penelitian ini relevan dengan teori Hawkins yang manyatakan bahwa gaya hidup seseorang mempengaruhi kebutuhan, keinginan, serta perilakunya termasuk perilaku membeli. ${ }^{17}$ Selain itu, penelitian sebelumnya yang dilakukan oleh Tarigan (2016) mengenai pengaruh gaya hidup, label halal dan harga terhadap keputusan pembelian kometik Wardah terdapat pengaruh positif dan signifikan terhadap keputusan pembelian kosmetik Wardah di

\footnotetext{
${ }^{16}$ Ujang Sumarwan, Perilaku Konsumen, 257.

17 Vinna Sri Yuniarti, Perilaku Kosumen Teori dan Praktik, 136.
} 
mana kosmetik Wardah ini merupakan salah satu produk halal di Indonesia. ${ }^{18}$ Hasil ini juga sejalan dengan penelitian yang dilakukan oleh Risnawati dan Hasby (2015) mengenai pengaruh gaya hidup terhadap proses keputusan pembelian produk Revlon studi pada remaja perempuan kota Bogor. Penelitian ini menghasilkan kesimpulan bahwa variabel gaya hidup, yang terdiri dari activities, interest dan opinion secara simultan berpengaruh terhadap variabel keputusan pembelian. ${ }^{19}$

Koefisien variabel gaya hidup sebesar 0.439 yang berarti apabila terjadi perubahan pada variabel gaya hidup sebesar 1 persen, maka akan memberikan dampak terhadap konsumen atau pengguna kosmetik Safi sebesar 0.439 atau $43.9 \%$ dengan asumsi variabel lain dianggap tetap. Koefisien variabel gaya hidup memiliki pengaruh positif terhadap keputusan pembelian kosmetik Safi pada mahasiswi Universitas Muhammadiyah Yogyakarta.

Responden beranggapan jika kosmetik Safi memberikan ketertarikan tersendiri dari pada kosmetik lain yang mana perannya penting dalam aktivitas sehari-hari guna menunjang penampilan. Di sisi lain, kosmetik Safi adalah kosmetik yang tren dan banyak diminati oleh kaum perempuan. Kosmetik Safi bagi mahasiswi merupakan barang komplementer atau barang yang harus ada guna menunjang penampilannya. Dalam Islam sendiri segala hal yang digunakan untuk memenuhi kebutuhan dan menunjang gaya hidup harus bersifat halal secara hukum Islam, serta tayyib atau tidak akan merugikan atau menyakiti siapapun. Mahasiswi pada zaman sekarang ini sudah terbiasa dengan gaya hidup yang halal di mana ketika mereka dihadapkan dengan pilihan untuk memilih suatu produk yang sudah berlabel halal dan belum memiliki label halal. Maka mahasiswi akan memilih produk yang sudah berlabel halal, di samping untuk menunjang penampilan juga guna mendapat keridaan Allah.

Dari kuesioner yang disebar oleh peneliti kepada responden pada variabel gaya hidup, responden paling banyak menjawab bahwa kosmetik Safi memiliki warna yang natural dibanding kosmetik merek lain.

\section{Pengaruh Label Halal terhadap Keputusan Pembelian Kosmetik Safi}

Berdasarkan hasil uji hipotesis menunjukkan nilai signifikan sebesar 0.275 dengan nilai probabilitasnya sebesar 0.020. Nilai probabilitas pada variabel label halal lebih kecil dari 0.05 . Hal ini berarti label halal mempunyai pengaruh positif signifikan terhadap keputusan pembelian, sehingga hipotesis yang menyatakan adanya pengaruh antara label halal dan keputusan pembelian didukung.

Adanya label halal pada kemasan produk menjadikan pertimbangan dan memudahkan untuk mengindentifikasi produk sehingga lebih meyakinkan kosnumen dalam membeli produk. Dari presepsi tersebut proses di mana orang memilih dan mempertimbangkan produk yang akan dikonsumsi. Dengan adanya label halal dalam kemasan produk, pada akhirnya akan mempengaruhi keputusan pembelian konsumen. Menggunakan kosmetik halal menjadi rutinitas dalam keseharian yang disukai, selain menjadikan sebuah kebutuhan penggunaan

\footnotetext{
${ }^{18}$ Dewi Eka Setia Tarigan, "Pengaruh Gaya Hidup", 90.

${ }^{19}$ Risnawati Lestari dan Imanuddin Hasbi, "Pengaruh Gaya Hidup Terhadap Proses Keputusan Pembelian Produk Revlon (Studi Pada Remaja Perempuan Kota Bogor)", e-Proceeding of Management, Volume 2, Nomor 1 (April 2015), 729.
} 
kosmetik halal yang termasuk dalam barang mewah akan menggambarkan pemiliknya, sehingga produk kosmetik halal lebih dipilih untuk menjaga penampilan.

Pernyataan ini sesuai dengan Kotler dan Keller yang menyatakan bahwa keputsan pembelian dapat dipengaruhi oleh keyakinan dan sikap. Adanya label halal pada kemasan akan memberikan pengaruh bagi konsumen khususnya masyarakat muslim untuk menggunakan produk-produk halal karena adanya label halal dapat menciptakan rasa aman dan nyaman dalam mengonsumsi produk tersebut sehingga meningkatkan kepercayaan serta minat beli. ${ }^{20}$ Selain itu, hasil penelitian ini relevan dengan penelitian yang dilakukan Lalujan pada tahun $2016^{21}$, Puspita dan Suryoko di tahun $2016^{22}$ dan Faadhilah pada tahun $2018^{23}$ yang memiliki kesimpulan serupa, yaitu variabel label halal berpengaruh secara signifikan terhadap keputusan pembelian. Hasil ini juga sejalan dengan penelitian yang dilakukan oleh Widyaningrum (2016) mengenai pengaruh label halal dan celebrity endorse terhadap keputusan pembelian kosmetik Wardah pada konsumen di Ponorogo di mana variabel label halal memiliki pengaruh positif dan signifikan terhadap keputusan pembelian. ${ }^{24}$

Koefisien variabel label halal sebesar 0.275 yang berarti apabila terjadi perubahan pada label halal sebesar 1 persen, maka akan memberikan dampak terhadap konsumen atau pengguna kosmetik Safi sebesar 0.275 atau 27.5\% dengan asumsi variabel lain dianggap tetap. Koefisien variabel label halal memiliki pengaruh positif terhadap keputusan pembelian kosmetik Safi pada mahasiswi Universitas Muhammadiyah Yogyakarta.

Responden beranggapan jika label halal pada kosmetik Safi menjamin kehalalan produk sehingga memberikan ketertarikan tersendiri dari pada kosmetik lain. Selain itu, informasi label halal LPPOM MUI pada kemasan memperkuat bahwa Safi tidak mengandung bahan yang berbahaya sehingga responden lebih yakin untuk menggunakan kosmetik Safi dalam kesehariannya. Label halal pada kemasan kosmetik sendiri pada saat sekarang ini sedang tumbuh di dunia bisnis karena menjadi daya tarik tersendiri ketika suatu kosmetik mencantumkan label halal.

Dari kuesioner yang disebar oleh peneliti kepada responden pada variabel label halal, responden paling banyak menjawab bahwa label halal yang dimiliki kosmetik Safi adalah bersifat resmi sehingga tidak diragukan lagi kualitasnya.

\section{Pengaruh Harga terhadap Keputusan Pembelian Kosmetik Safi}

Berdasarkan hasil uji hipotesis yang menunjukan nilai signifikan sebesar 0.316 dengan nilai probabilitasnya sebesar 0.002 . Nilai probabilitas pada variabel label halal lebih kecil dari 0.05. Hal ini berarti harga mempunyai pengaruh positif signifikan terhadap keputusan pembelian, sehingga hipotesis yang menyatakan adanya pengaruh antara harga dan keputusan pembelian didukung.

Harga berkaitan dengan bagaimana informasinya dipahami seluruhnya oleh konsumen dan memberikan makna yang dalam bagi mereka. Pendekatan untuk memahami persepsi harga

\footnotetext{
${ }^{20}$ Philip Kotler dan Lane Keller, Manajemen Pemasaran, 136.

${ }^{21}$ David I. O. Lalujan, dkk, "Analyzing the Influence of Brand Image", 145-155.

${ }^{22}$ R. Puspita dan S. Suryoko, "Pengaruh Iklan, Harga", 418-425.

${ }^{23}$ Fauz Novia Faadhilah, "Pengaruh Gaya Hidup", 133-142

${ }^{24}$ P. W. Widyaningrum, "Pengaruh Label Halal dan Celebrity Endorser Terhadap Keputusan Pembelian (Survei Pada Konsumen Wardah Ponorogo)", Jurnal Ekonomi Syariah Indonesia, Volume 6, Nomor 2 (2016), 83-98.
} 
adalah pemrosesan informasi yang dikemukakan oleh Jacoby dan Olson. Konsumen dapat membuat perbandingan antara harga yang ditetapkan dengan sebuah harga atau rentang harga yang telah terbentuk dalam benak mereka untu produk tersebut. ${ }^{25}$

Pergeseran-pergeseran paradigma, dinamika gaya hidup, serta berbagai perubahan lingkungan lain telah memberi dampak bagaimana konsumen memandang harga produk atau jasa yang akan dikonsumsinya. Harga menimbulkan berbagai interpretasi di mata konsumen. Konsumen akan memiliki interpretasi dan presepsi yang berbeda-beda tergantung dari karakteristik pribadi (motivasi, sikap, konsep diri dan sebagainya), latar belakang (sosial, ekonomi, demografi dan sebagainya), pengalaman (belajar), serta pengaruh lingkungannya. Dengan demikian penilaian terhadap harga suatu produk dikatakan murah, mahal atau biasa saja, dari setiap individu tidak sama karena tergantung persepsi individu yang dilatarbelakangi oleh lingkungan kehidupan dan kondisi individu. Pelanggan dalam menilai harga suatu produk bukan hanya dari nilai nominal secara absolut tetapi melalui persepsi pada harga. Suatu perusahaan perlu memonitor harga yang ditetapkan oleh para pesaing agar harga yang ditetapkan oleh perusahaan tidak terlalu tinggi atau sebaliknya, sehingga harga yang ditawarkan dapat menimbulkan keinginan konsumen untuk melakukan pembelian.

Hasil ini sejalan dengan penelitian yang dilakukan oleh Puspita dan Suryoko (2017) mengenai pengaruh iklan, harga dan kepercayaan merek terhadap terhadap keputusan pembelian kosmetik Revlon pada mahasiswa S1 Universitas Diponerogo. Di mana variabel harga memiliki pengaruh positif dan signifikan terhadap keputusan pembelian dengan nilai koefisien $0.338 .^{26}$

Koefisien variabel harga sebesar 0.316 yang berarti apabila terjadi perubahan pada variabel gaya hidup sebesar 1 persen, maka akan memberikan dampak terhadap konsumen atau pengguna kosmetik Safi sebesar 0.439 atau 31.6\% dengan asumsi variabel lain dianggap tetap. Koefisien variabel harga memiliki pengaruh positif terhadap keputusan pembelian kosmetik Safi pada mahasiswi Universitas Muhammadiyah Yogyakarta.

Responden beranggapan jika harga kosmetik Safi memberikan manfaat yang sesuai dengan harganya serta kualitasnya yang mampu bersaing dengan produk lain yang memiliki harga lebih tinggi di atas Safi dan kualitasnya sesuai dengan harga yang ditawarkan. Dari kuesioner yang disebar oleh peneliti kepada responden pada variabel harga, responden paling banyak menjawab bahwa harga kosmetik Safi memiliki memiliki harga yang sangat terjangkau namun kualitasnya sangan baik.

\section{Kesimpulan}

Berdasarkan analisis dan pembahasan di atas, maka dapat disimpulkan sebagai berikut. Pertama, dari hasil pengujian regresi linear berganda yang telah dilakukan maka dapat disimpulkan bahwa variabel gaya hidup memiliki pengaruh positif dan signifikan terhadap keputusan pembelian kosmetik Safi dengan nilai t hitung yaitu 5.608. Kedua, dari hasil pengujian regresi linear berganda yang telah dilakukan maka dapat disimpulkan bahwa variabel

\footnotetext{
${ }^{25}$ R. K. Sari, dkk, "The Truth Behind the Decision of Consumers in Buying Counterfeit Cosmetics Product: A Qualitative Phenomenological Research", JEMA: Jurnal Ilmiah Bidang Akuntansi dan Manajemen, Volume 15, Nomor 2 (2018), 25.

${ }^{26}$ R. Puspita dan S. Suryoko, "Pengaruh Iklan, Harga", 418-425.
} 
label halal memiliki pengaruh positif dan signifikan terhadap keputusan pembelian kosmetik Safi dengan nilai t hitung yaitu 2.360. Ketiga, dari hasil pengujian regresi linear berganda yang telah dilakukan maka dapat disimpulkan bahwa variabel harga memiliki pengaruh positif dan signifikan terhadap keputusan pembelian kosmetik Safi dengan nilai t hitung yaitu 3.209.

\section{Daftar Rujukan}

Aspan, Iskandar, dkk. "The Effect of Halal Label, Halal Awarness, Product Price and Brand Image to the Purchasing Decision on Cosmetic Products (Case Study on Consumers of Sari Ayu Marta Tilaar in Binjai City)", International Journal of Global Sustainability, Volume 1, Nomor 1 (2017).

Basuki, A. T. Ekonometrika dan Aplikasi dalam Ekonomi. Yogyakarta: Danisa Media, 2017.

Lalujan, David I. O., dkk. "Analyzing the Influence of Brand Image, Perceived Price and Perceived Quality on Consumer Buying Decision of Low Cost Green Car (Case Study of Astra Toyota Agya at Manado)", Efisiensi, Volume 16, Nomor 4 (2016).

Faadhilah, Fauz Novia. "Pengaruh Gaya Hidup Konsumtif dan Beauty Vlogger sebagai Kelompok Referensi Terhadap Keputusan Pembelian Kosmetik Studi Kasus Pada Remaja Perempuan Pengguna Kosmetik Korea di Surabaya”, Jurnal Ilmu Manajemen, Volume 7, Nomor 1 (2018).

Ferdinand, T. "Analyzing the Influence of Price and Product Quality on Buying Decision", Jurnal EMBA, Volume 2, Nomor 3 (2014).

Ghozali, Imam. Aplikasi Analisis Multivariate dengan Program SPSS. Semarang: Badan Penerbit Universitas Diponegoro, 2011.

Girinda. A. Dari Sertifikat Menuju Labelisasi Halal: LPPOM MUI. Jakarta: Pustaka Jurnal Halal, 2008.

Kotler, Philip dan Lane Keller. Manajemen Pemasaran. Jakarta: Erlangga Pearson Education, 2009.

Kottler, Philip dan Gary Amstrong. Manajeman Pemasaran, Jilid 1. Jakarta: Ghalia Indonesia 2001.

Lestari, Risnawati dan Imanuddin Hasbi. "Pengaruh Gaya Hidup Terhadap Proses Keputusan Pembelian Produk Revlon (Studi Pada Remaja Perempuan Kota Bogor)", e-Proceeding of Management, Volume 2, Nomor 1 (April 2015).

Pangestu, Suci Dewi dan Sri Suryoko. "Pengaruh Gaya Hidup (Lifestyle) dan Harga Terhadap Keputusan Pembelian (Studi Kasus pada Pelanggan Peacockoffie Semarang)", Jurnal Administrasi Bisnis, Volume 5, Nomor 1 (2016).

Pertiwi, A. dan B. Hermana. "Analisis Pengaruh Citra Merek, Kualitas Produk, Iklan, dan Harga Terhadap Keputusan Pembelian Produk Kosmetik Wardah (Studi Kasus pada Mahasiswi Jurusan Manajemen Fakultas Ekonomi Universitas Gunadarma yang Mengambil Kuliah di Kampus Depok)”, Jurnal Ilmiah Ekonomi Bisnis, Volume 22, Nomor 3 (2017).

Puspita, R. dan S. Suryoko. "Pengaruh Iklan, Harga, dan Kepercayaan Merek Terhadap Keputusan Pembelian Kosmetik Revlon (Studi Pada Mahasiswa S1 Universitas Diponegoro)", Jurnal Ilmu Administrasi Bisnis, Volume 6, Nomor 3 (2017).

Sari, R. K., dkk. "The Truth Behind the Decision of Consumers in Buying Counterfeit 
Cosmetics Product: A Qualitative Phenomenological Research", JEMA: Jurnal Ilmiah Bidang Akuntansi dan Manajemen, Volume 15, Nomor 2 (2018).

Sekaran, Uma. Metode Penelitian Untuk Bisnis. Jakarta: Penerbit Salemba Empat, 2011.

Sugiono. Metode Penelitian Bisnis. Bandung: Alfabeta, 2018.

Sumarwan, Ujang. Perilaku Konsumen (Teori dan Penerapannya dalam Pemasaran). Bogor: Penerbit Ghalia Indonesia, 2004.

Tarigan, Dewi Eka Setia. "Pengaruh Gaya Hidup, Label Halal dan Harga terhadap Keputusan

Pembelian Kosmetik Wardah pada Mahasiswa Program Studi Manajemen Fakultas

Ekonomi Universitas Medan Area Medan”. Jurnal Konsep Bisnis dan Manajemen. Volume 3, Nomor 1 (2016).

Widyaningrum, P. W. "Pengaruh Label Halal dan Celebrity Endorser Terhadap Keputusan Pembelian (Survei pada Konsumen Wardah Ponorogo)", Jurnal Ekonomi Syariah Indonesia, Volume 6, Nomor 2 (2016).

Yuniarti, Vinna Sri. Perilaku Kosumen Teori dan Praktik. Bandung: Pustaka Setia, 2015. 